\section{Willingness to Pay for Green Products vs Ecological Value System}

\author{
Agnieszka Leszczyńska \\ Maria Curie Sktodoroska University in Lublin \\ agnieszka.leszczynska@poczta.umcs.lublin.pl
}

\section{Willingness to Pay for Green Products vs Ecological Value System}

\begin{abstract}
Environmental concern has been an important issue for a few decades and the extent of consumer demand for eco-friendly consumption has increased. The article presents research results concerning the willingness to pay (WTP) for selected green products, defined by the auction method. Moreover, the paper presents the interrelations between the perceived benefits, individual value system and the WTP.

Purpose - The aim of research is evaluation of willingness to pay (WTP) for green products, assessment of the interrelations between willingness and the individual values, perceived benefits. Design/methodology - The experiment in a form of the auction was carried out in order to assess the current WTP. Three non-eco-friendly products and their ecological equivalents were chosen. The auction was carried out among 20 persons. For evaluation of perceived benefits and individual system of values a questionnaire form was used.

Findings - Not eco-friendly products were evaluated slightly higher than their real (market) value. Green products were evaluated below their market value. Considering a system of values, the self-enhancement values are mostly interrelated with the perceived environmental benefits and product functionality. In the group of people with dominating self-transcendence values a connection exists between the purchase of green products and perceived individual benefits.

Research implications - Results can constitute a starting point for the research on the influence of a value system on purchase decisions of green products.

Practical implications - Results can be used for establishing process of green products, and making plans for their marketing campaigns.

Social implications - Results increase the knowledge about the perception and the reception of green products by clients with different systems of values.

Originality/value - The article complements former research through combining the factors such as perceived benefits from using green products, user's individual value system, and environmental effects of product production with the WTP.
\end{abstract}

Paper type - research

Key words: willingness to pay, ecological product

\title{
Introduction
}

In the previous literature investigating consumer's intention to purchase green products, it is revealed that consumers show a strong positive attitude towards green products. Therefore, consumers are price and quality sensitive when it comes to "buying green". Simultaneously green consumers who are environmentally conscious not always behave in accordance with their intention to purchase green products. The production costs of

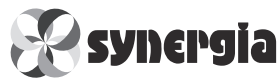

International Journal of Synergy and Research Vol. 3, 2014 p. $67-77$ 
IJSR 3

green products are generally higher than general products. Therefore, the prices of green products are usually higher than general products. High price of green products is one of the important reasons why consumers avoid buying them. Researchers have attempted to identify green consumer's profiles with an intention to characterize green market segments using demographic variables (McKenzie, 1991; Roberts, 1996; Titterington et al., 1996; Brown and Wahlers, 1998). The assumed variables were usually age, gender, knowledge level, income and ecological awareness. This article complements that research through combining the factors such as perceived benefits from using green products, user's individual value system, and environmental effects of product production, with the WTP. The purposes of this study are to:

- find out consumers' willingness to pay (WTP) for eco-friendly products,

- assess the interrelations between the individual values, perceived benefits and the willingness to pay for eco-friendly products.

The article has the following structure: section one includes the presentation of the WTP issue and its determining conditions. Section two presents the research methodology and their results divided into subcategories (WTP for ecological products, benefits assessment, determining the value system) and Conclusions.

\section{Willingness to pay for ecological products}

Willingness to pay (WTP) is the price or dollar amount that someone is willing to give up or pay to acquire goods or services. It could also be defined as the maximum amount of money that may be contributed by an individual to equalize a utility change. The WTP function identifies the price an individual is willing to pay for a given level of quality (q) given specific levels of price (p) and utility (U) (Lusk and Hudson, 2004). Willingness to pay is based on the principle that the maximum amount of money an individual is willing to pay for a commodity is an indicator of the value he/she puts on that commodity. Three basic methods have been used to elicit consumers' economic value or willingness to pay for preferences; these include personal interviews, mail surveys and experimental auctions (Umberger et al., 2002). The most widely used techniques to obtain WTP estimates are contingent valuation, conjoint analysis, and experimental auctions. Conjoint analysis and contingent valuation are hypothetical valuation methods, which use survey responses to elicit consumer's willingness-topay. Experimental auctions also determine how much consumers will pay for goods or services but in a more or less real situation.

According to Bjerke (1992), about $42 \%$ of the respondents are willing to pay a premium for ecological products. Grunert and Kristensen (1992) find that about $60 \%$ are willing to pay a premium. By referencing the organic food, Gil et al. (2000) showed that in Spain only likely and actual organic consumers were willing to pay a premium of 15-25 percent for organic food. Canavari et al. (2003) found that the proposed premium price for organic peaches and apples was accepted by $65.8 \%$ of the Italian respondents of their survey. Millock (2002) found that $35 \%$ of the respondents in Denmark were willing to pay more for any type of organic products. These results indicate that there is a major group of consumers who consider views on organic products in their purchasing decisions. On the other hand, some authors indicate that there is a gap between intentions and behaviors 
in the field of purchasing ecological products. There is a group of over $30 \%$ of consumers (Bjerke, 1992) who have positive attitudes but who do not buy ecological products, and a group of app. 16\% (Bjerke, 1992) who are willing to pay without it reflecting in the market shares. The fundamental explanation of the aforementioned gap are over-excessive costs. Aryal et al. (2009) found that lack of information available to consumers, higher prices over those of conventional foods, and the limited and erratic domestic supply were factors that influenced consumers' willingness to purchase. Research on estimating consumer's WTP have been increasing. However, the subjects of research are limited to public goods such as parks and forests. There are a few researches focusing on consumer goods, but they are also limited to agricultural and fishery products. Prior WTP literature mainly examines ways to measure WTP (Miller, 2011), consumer profiles (e.g. demographics, attitudes that lead to distinct WTP levels (Laroche, 2001) and the specific relationships of WTP with consumer knowledge (Bechwati, 2011) or product design (Kristensen, 2012). A significant number of papers are based on self-reporting. For example, Thøgersen (2002) measured behavior concerning organic and non-organic wine. Harland, Staats, and Wilke (1999) studied self-reported behavior for five different ecological behaviors (including turning off the faucet while brushing one's teeth, purchasing energy-saving light bulbs, and using other forms of transportation than the car). However, it may turn out that the weak spot of these papers is the discrepancy between the declarations and real-life actions. Thus, their relations concerning the behaviors and views may not constitute a fully reliable source.

\section{Selected WTP conditions}

WTP for organic products can be explained on the basis of the VNB theory. According to this theory, the determinant of pro-environmental behaviors (in this case - the purchases) is the awareness of consequences understood as an individual's beliefs about the adverse consequences of environmental problems. The theory is an extension of Schwartz's (1977) norm-activation theory of altruistic behavior (see also Schwartz \& Howard, 1981) augmented with Schwartz's $(1992,1994)$ universal value structure. In previous research, it is proposed that egoistic (e.g. threat to one's health), altruistic (e.g. threat to future generations), and biospheric (e.g. threats to animals and nature) or environmental concerns and values are relevant for understanding pro-environmental behaviors (De Groot and Steg 2007; Schultz 2001; Stern et al. 1995). Environmental concern refers to worry associated with adverse consequences of environmental problems (e.g. Schultz et al. 2004) or to beliefs about adverse consequences of environmental problems (e.g. Stern et al. 1995).

The factor that affects the WTP for organic products are also the perceived benefits. (Kayaman \& Arasli, 2007; Kim \& Kim, 2005; Ottman, 2011). The conducted research proved that clients are willing to pay a premium for environment-friendly products provided their quality is higher than this of conventional products. (D'Souza et al., 2007). Consumers who consider the environment to be important will evaluate environmental consequences related to the product purchase. If these consequences are significant enough for the recipient, then this may result in purchasing the green product. Such a product not only fulfils the consumer's needs but also provides long-term benefits. Also the image of the product is important for a potential recipient. Products with
Willingness to

Pay for Green Products vs Ecological Value System 
IJSR 3

positive social overtones (products improving the quality of life and products that are highly-regarded) are in higher demand (Orth, Wolf, \& Dodd, 2005). Webster (1975) defined a socially conscious consumer as a consumer who takes into account the public consequences of her/his private consumption or who attempts to use her/his purchasing power to bring about social change. That is, consumers incorporate social issues into their purchase decisions by evaluating the consequences of their consumption upon society. Goldstein, Cialdini, and Griskevicius (2008) provide empirical support for the influence of social norms on sustainable behaviors.

Moreover, the willingness to buy organic products is highly dependent on the value system. Values are the abstract types that may be used for describing human behavior in accordance with the inner world: they are the basis for assessing behaviors and events (Barber et al., 2012; Follows \& Jobber, 2000). Generally, they can be divided into: selftranscendence and self-enhancement. Self-transcendence consists of an active concern for others and the desire to work for the good of society. It is a personal journey of selfdiscovery, where one strives for greater perfection, higher perspective, and moves beyond prior concepts of behavioral limitations, which goes beyond ego (Barber et al., 2012; Follows \& Jobber, 2000; Schwartz, 1992, 1994). Self-enhancement reflects the extent to which individuals are motivated to enhance their own personal interests and how they see themselves. The values affect motivation and trigger actions. Kilbourne, Grünhagen, and Foley (2005) further suggested that individuals higher in self-enhancement tend to be more materialistic than those higher in self-transcendence, and consequently may be less concerned about the impact their consumption has on the environment. However, self-enhancement may also encompass the care for the condition of the environment, if its condition directly affects the decision-maker. Then, even the self-enhancing individual will be characterized by higher willingness to pay for eco-friendly products.

\section{Methodology}

The aim of the research was to: 1) assess the WTP for selected ecological products 2) divide consumers into clusters considering their WTP, 3) determine certain identical features that characterize selected consumer clusters. The research was carried out in stages. The first stage was focused on the WTP for ecological products and their nonecological counterparts. The experiment in a form of the auction was carried out in order to assess the current WTP. Experimental auction methods have been cited as having the potential to provide more reliable measures of willingness to pay than a hypothetical survey method (Umberger et al., 2002). The products put up for auction have been presented in Table 1. All brand names were removed to avoid the influence of brand recognition during the evaluation process.

The auction was carried out among 20 persons: all in one place. It was carried out after the presentation of the rules, in a specified (limited) time period. The auction was held by the president of the auction commission who informed the bidders about the products. The asking price was called out and bid increments were accepted by the president of the auction commission. He informed the bidders about the fact that after the third call-out of the highest bid the further bid increments will not be accepted. The auction was carried out by word of mouth. 
Traditional product

A1: Sweet red wine originating from hot South Italy. It is not as strong and heavy as liqueur wines. The vineyards are over 30 years old. Intensive aroma of forest fruits and strawberries. After a short fermentation process, the wine ages in a tun. Thanks to the balanced flavor, it maintains crispness.

B1: Ladies sweater made of thick, heavy wool. The pattern matches plain trousers and skirts. Fashionable cut and fit. Sizes from $\mathrm{S}$ to $\mathrm{L}$.

C1: Cream effectively conditions and protects dry skin. It is fast-absorbing and does not leave an oily layer. Contains shea butter and beneficial active substances: panthenol and beeswax.

Source: Author's compilation

\section{Ecological product}

A2: Rich, barreled chardonnay with a distinct personality. A single vineyard rich in calcium carbonate is located in a cool area of the Pacific. Grapes are picked by hand. The aging process lasts 11 months in barrels made of French oak. A strong bouquet of citruses with a touch of caramel. A wellbalanced, intense, long-lasting taste.

P2: Product made of ecological wool produced in accordance with restrictive regulations. It originates from sheep pastured on natural grazing lands. A fashionable ornament around the neck.

C2: Hand cream with Echinacea and grape seed oil. Fastabsorbing, after use the skin remains smooth and elastic. A pomegranate essence strengthens and moisturizes the skin. Grape seed oil has regenerating properties. $100 \%$ of ingredients are all-natural. Free of artificial dyes and aromas.
Willingness to

Pay for Green Products vs

Ecological Value

System

After the auction was concluded, the bidders were asked to define a maximum amount they were willing to bid for a given product (regardless of the auction result). These prices were recorded separately.

The next research stage assessed the perceived benefits from purchasing the presented goods and determined the individual value system. The research tool used was a survey prepared specially for the research goal. A 1-5 scale was used, where 1 is the lowest possible grade. The perceived benefits encompassed 5 categories: economic benefits, individual benefits ("I take pleasure in using the product"), functional benefits, ("the product is characterized by proper functionality and quality"), environmental benefits ("I perceive the product as environmentally friendly"), social benefits ("the product has a very positive social image"). On the other hand, the value system was assessed in relation to the works of Schwartz (1992, 1994), Follows and Jobber (2000). The self-transcendence category included two sub-scales: universalism (equality, unity with nature, and social justice) and benevolence (loyalty). Self-enhancement included three sub-scales: achievement (successful), hedonism (pleasure), and power (social power). Participants assessed each of the above values by answering the following question: "How important are the following words to you?". The additional question regarded the importance of the impact on the environment that the production of a given product has. In order to assess it, the following question was used: "To what extent is the product production impact on the environment important to me?". Participants for both the survey and auction were the same consumers. These persons were interested in participating in the experiment. All of them were over 18 years of age and selected randomly. The research sample encompassed 40 persons, including 30 women. The research stages were presented in the following table: 


\section{IJSR}

3

\section{Table 2:}

Study design
Table 3:

Achieved price (in PLN)

\begin{tabular}{|c|c|}
\hline Stage & Effect \\
\hline \multicolumn{2}{|l|}{ Research sample selection } \\
\hline Organizing and carrying out the auction & Determining the maximum WTP for a group \\
\hline $\begin{array}{l}\text { Determining the maximum amount the participants are } \\
\text { willing to bid for the product }\end{array}$ & Determining the maximum individual WTP \\
\hline \multicolumn{2}{|l|}{$\begin{array}{l}\text { Carrying out surveys without considering the division of } \\
\text { the respondents }\end{array}$} \\
\hline Respondent clustering & $\begin{array}{l}\text { Clustering the uniform groups of consumers according to } \\
\text { their WTP }\end{array}$ \\
\hline Data comparison and statistical analysis of results & $\begin{array}{l}\text { Assessing the interrelations between: WTP - value system } \\
\text { - benefit perception }\end{array}$ \\
\hline Discussion regarding the results & \\
\hline
\end{tabular}

Source: Author's compilation

\section{Research results}

\section{WTP for ecological products}

The auction began with a sum amounting to the $30 \%$ of the product market value. Prices achieved in the course of the auction were compiled in the following table.

\begin{tabular}{cccc}
\hline Product & Market Price & Bid price & Price difference \\
\hline A1 & 46 & 52 & 6 \\
A2 & 82 & 80 & 2 \\
B1 & 61 & 63 & 2 \\
B2 & 129 & 125 & 4 \\
C1 & 5.5 & 40 & 34.5 \\
C2 & 18.5 & 26 & 7.5 \\
\hline
\end{tabular}

Source: Author's compilation

Prices achieved in case of medium or high value products do not differ drastically from the market price. The bid price is not significantly different from the market price. There is a certain regularity to be observed here: non-ecological products were valuated slightly higher than their real (market) price. On the other hand, green products were valuated below their market value. These results indicate that in case of dearer products, providing the information on a product affects the consumers' perception of its economic value - participants were willing to pay nearly the same price for each product as the market price.

The opposite trend occurred in case of products of low value (below 50 PLN). Prices achieved in the course of the auction exceeded the market value of the products; this concerns both non-ecological and ecological products. In case of ecological products, the surplus (overpayment) is lower than the one of non-ecological product, the value of which was exceeded seven-fold. 


\section{Assessing the benefits, determining the value system}

The assessment of perceived benefits was carried out for pro-ecological products. The lowest economic value of ecological product purchase indicated by respondents concerned the cheapest product (Table 4). This is caused by high prices in this category of goods in relation to conventional products, which decreases their value in the eyes of potential recipients. In case of all the products the respondents have given a high mark to the individual benefits that go with them. The value exceeded 3 on a 1 to 5 scale. The highest benefit was recorded for the individualized product of everyday use (B). Respondents valuated the functionality of green products as average. Is has to be noted that these values do not significantly differ from one another as regards the type of a product. Social benefits were given slightly lower marks. The biggest difference was recorded for the $\mathrm{C}$ product, which is probably due to perceiving this product category as not interlinked with luxury goods or fashion.

\begin{tabular}{cccccc}
\hline Product & Economic benefit & Individual benefit & Functionality & Environmental benefit & Social benefit \\
\hline A & 3.33 & 3.16 & 2.33 & 3 & 3 \\
B & 3.16 & 4.16 & 3.16 & 3.33 & 3.2 \\
C & 2.16 & 3.83 & 3.66 & 3.5 & 2.8 \\
\hline
\end{tabular}

(scale from 1 to 5 )

Source: Author's compilation

The self-enhancement values are mostly interrelated with the perceived environmental benefits and product functionality (Table 5). What is surprising is the low correlation level between individual benefits and the value system. According to the respondents, green products usage is not significantly correlated with focusing on individual benefits. On the other hand, there is a connection between individual benefits and the purchasing of green products among persons with dominant selftranscendence values. Respondents with such an attitude indicate that green products provide them with individual benefits. However, this group has valuated the environmental and social benefits as well as functionality of ecological products in the same way.

Persons with self-transcendent attitude pay more attention to the production effects (valuated as an impact of product production method on the environment). This is in accordance with the most fundamental values of this system - caring for well-being of people and the environment.

\begin{tabular}{lcccccc}
\hline & Economic benefit & Individual benefit & Functionality & Environmental benefit & Social benefit & Level \\
\hline Self-enhancement & 0.19 & 0.37 & 0.47 & 0.54 & 0.35 & 0.2 \\
Self-transcendence & 0.06 & 0.90 & 0.63 & 0.65 & 0.69 & 0.47 \\
Level & 0.30 & 0.62 & 0.20 & 0.17 & 0.78 & \\
\hline
\end{tabular}

Source: Author's compilation
Willingness to

Pay for Green Products vs

Ecological Value

System

Table 4:

Perceiving the benefits of green products

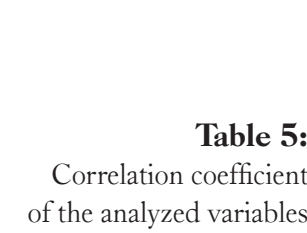




\section{IJSR}

3
Table 6:

Values, perceived benefits of green products (Scale from 1 to 5$)$

\section{Respondent clustering}

The participants were clustered considering the maximum amount they would be willing to pay for a given product. A two-step clustering procedure was adopted: (1) a hierarchical cluster analysis to identify the appropriate number of clusters, and (2) a K-means cluster analysis, providing further elaborative information on the cluster membership. The hierarchical cluster analysis procedure was applied to the data after computing several solutions for different numbers of clusters (e.g. two, three, four, etc.). Two categories named as "high price" and "low price" were clustered (Table 6). As regards green products, the low price group encompassed respondents whose WTP for these products was analogous or even lower than the WTP for non-ecological products $(66 \%)$. In case of non-ecological products there were also two clusters, whereby the low price group encompassed respondents willing to pay for a product less than $75 \%$ of its market value ( $25 \%$ of respondents). Using the K-means, resulting clusters were statistically different from one another (between clusters for each product category) for ecological $[\mathrm{F}=24,75, \mathrm{p}<.05]$ and for non-ecological $[\mathrm{F}=125,49, \mathrm{p}<.05]$. Further result analysis was carried out considering the clustered groups.

In case of green products, the high price group attaches more importance to the self-transcendence values (this group gave higher marks to values, i.e. conformity with nature, social justice). The persons with this attitude give higher marks to environmental and individual benefits coming from green products. They are willing to pay premium for environmentally friendly products. The low price group to a greater extent assumes values that are characteristic for the self-enhancement system. This group gave higher marks to the need for achievements and power. The group is therefore motivated by individual benefits, not social interests. Although their WTP for green products is analogous to the WTP for non-ecological ones, there are also respondents in this group who declared that the product's impact on the environment is meaningful to them. However these declarations are not followed by real-life actions.

\begin{tabular}{lccc}
\hline & High price & Low price & Pairwise testing \\
\hline Economic benefits & 3.6 & 1.9 & $\mathrm{~F}=17,4 \mathrm{p}<.05$ \\
Individual benefits & 4.3 & 3.2 & $\mathrm{~F}=35,9 \mathrm{p}<.05$ \\
Functionality & 3.9 & 2.8 & $\mathrm{~F}=48,7 \mathrm{p}<.05$ \\
Environmental benefits & 4.1 & 2.2 & $\mathrm{~F}=53,4 \mathrm{p}<.05$ \\
Social benefits & 3.1 & 1.9 & $\mathrm{~F}=24,1 \mathrm{p}<.05$ \\
Self-transcendence & 4.5 & 2.9 & $\mathrm{~F}=49,1 \mathrm{p}<.05$ \\
Self-enhancement & 3.3 & 3.7 & $\mathrm{~F}=32,7 \mathrm{p}<.05$ \\
Impact on the environment & 3.8 & 3.3 & $\mathrm{~F}=34,3 \mathrm{p}<.05$ \\
\hline
\end{tabular}

Source: Author's compilation

In case of non-ecological products, the low price respondent group attaches most importance to functionality and economic values. The reason for making purchases in this group are economic and technical reasons. By referencing the consumer purchasing 
behavior theory it is possible to indicate the purchasing that is based on habits, where consumer behaviors are shaped by personal factors. Regarding the non-ecological products, the high price respondent group reflected the product market value (or value close to market value) in their purchasing decisions. This group is connected with selfenhancement values to a greater degree. Similar correlation coefficients were obtained for economic, individual and environmental benefits which means that these criteria are equally important in the course of purchasing decisions. The group corresponds to consumers who make purchasing decisions on the basis of inner preferences. Simultaneously, the high price group is aware of the environmental consequences of choosing certain products - their importance was given a 3.1 mark. That is, they feel it is important to care about the ecological consequences as a whole, but also view status and self-satisfaction as more important when making purchasing decisions.

\section{Implications}

The obtained results confirm the results of previous research. Biospheric environmental concerns and a cluster of altruistic-biospheric values, referred to as a self-transcendence value orientation, are positively related to a variety of pro-environmental behaviors (Nordlund and Garvill, 2003; Schultz et al. 2005). Therefore, the self-transcendence values play an important role in motivating to purchase ecological products. People whose value systems are dominated by these values will be characterized by higher WTP for environmentally friendly products. In turn, a cluster of egoistic values, referred to as self-enhancement, has been found to be negatively related to non-ecological behaviors (Schultz et al. 2005). For marketers of green products, the challenge lies in how to identify environmental beliefs and values consumers hold about green products in order to target them. For those consumers who do not currently purchase green products, the question is whether and how they can be motivated to become potential green consumers. The research indicates the importance of price in shaping the WTP. Oftentimes, the resistance to pro-ecological purchases is the cost (Bazoche et al., 2008; Bennett \& Williams, 2011; Grail Research, 2009). Consumers may not understand why a PE product should cost more, hence their WTP is the same as in case of non-ecological products. Therefore, it is necessary to clearly and understandingly emphasize the benefits of purchasing ecological products and bring out factors that affect their price. Another conclusion concerns the importance of "image". As discussed earlier, consumers reporting high self-enhancement values place less importance on the social gratification a product provides and the related image with its ownership. The image, therefore, affects the product choice; products perceived as luxurious, unique or fashionable are highly regarded in the society. Building the image of ecological products as socially desired will have a positive influence on their WTP. For companies that intend to use the green product offering as a competitive advantage, it appears to be fundamental to emphasize benefits from purchasing ecological products (this concerns not only environmental benefits, but also individual and social ones) and reach consumers who treasure certain values. It is possible to cluster markets based on the three combined dimensions of price / perceived benefits / individual characteristics. This may turn out to be useful, particularly in the process of creating a promotional campaign for
Willingness to

Pay for Green Products vs Ecological Value System 
IJSR 3

ecological products. A major limitation of this study was assessing actual behavior using an auction method. Voelckner (2006) suggests that researchers should not depend on the auction participants' true valuations of the good because the participant's goal may be only attaining a winning bid. As a result, valuations obtained from an auction setting may differ from those in retail settings. Another limitation is the number of participants taking part in the experiment. An insignificant group of respondents may be insufficient for making general conclusions. Therefore, it is justified to juxtapose results with the research carried out on a more representative group.

\section{Bibliography}

Aryal, K.P., Chaudhary, P., Pandit, S. Sharma, G. (2009). Consumers' willingness to pay for organic products: a case from Kathmandu Valley. The Journal of Agriculture and Environment, 10, pp. 12-22.

Barber, N., Kuo, P., Bishop, M., Goodman, R. (2012). Measuring psychographics to assess purchase intention and willingness to pay. Journal of Consumer Marketing, 29(4), pp. 280-293.

Barber, N.A., Bishop, M., Gruen, T. (2014). Who pays more (or less) for pro-environmental consumer goods? Using the auction method to assess actual willingness-to-pay. Journal of Environmental Psychology, 40, pp. 218-227.

Bazoche, P., Deola, C., \& Soler, L. G. (2008). An experimental study of wine consumers' willingness to pay for environmental characteristics. 12th Congress of the European Association of Agriculture Economists, http://www.legrenelle-environment.fr/grenelleenvironment.

Bechwati, N.N. (2011). Willingness to pay for professional services. Journal of Product \& Brand Management 20(1), pp. 75-83.

Bennett, G., \& Williams, F. (2011). Mainstream green. The Red Papers, 4, pp. 1-131.

Bjerke, F. (1992). Forbrugernes interesse for økologiske produkter. Roskilde: Roskilde Universitetscenter: Institut for samfundsøkonomi og planlægning.

Brown, J., Wahlers, R. (1998) The environmentally concerned consumer: An exploratory study. Journal of Marketing Theory and Practice, 6(2), pp. 39-47.

Canavari, M., Nocella, G., Scarpa, R. (2003). Stated willingness to pay for environment-friendly production of apples and peaches: web-based versus in-person surveys. Paper presented at the 83rd EAAE Seminar, Chania, 4-6 September.

De Groot, J. I. M., Steg, L. (2007). Value orientation and environmental beliefs in five countries: Validity of an instrument to measure egoistic, altruistic and biospheric value orientations. Journal of Cross-Cultural Psychology, 38(3), pp. 318-332.

D'Souza, C., Taghian, M., Khosla, R. (2007). Examination of environmental beliefs and its impact on the influence of price, quality and demographic characteristics with respect to green purchase intention. Journal of Targeting, Measurement \& Analysis for Marketing, 15(2), pp. 69-78.

Follows, S. B., Jobber, D. (2000). Environmentally responsible purchase behaviour: A test of a consumer model. European Journal of Marketing, 34(5-6), pp. 723-746.

Gil, J.M., Gracia, A., Sanchez, M. (2000). Market segmentation and willingness to pay for organic products in Spain. International Food and Agribusiness Management Review, 3, 207-26.

Grail Research, LLC. (2009). The green revolution. Retrieved from http://grailresearch.com/pdf/ ContenPodsPdf/The_Green_Revolution.pdf.

Griskevicius, V., Cialdini, R. B., Goldstein, N. J. (2008). Peer influence: An underestimated and underemployed lever for change. Sloan Management Review 49, pp. 84-88.

Grunert, S. C. (1992). Den danske forbruger og økologiske fødevarer. Aarhus: The Aarhus School of Business, Department of Information Science. Series H62. 
Harland, P., Staats, H., Wilke, H. A. (1999). Explaining proenvironmental intention and behavior by personal norms and the theory of planned behavior. Journal of Applied Social Psychology, 29(12), pp. 2505-2528.

Kayaman, R., Arasli, H. (2007). Customer based brand equity: Evidence from the hotel industry. Journal of Managing Service Quality, 17(1), pp. 92-109.

Kilbourne, W. E., Grünhagen, M., Foley, J. (2005). A cross-cultural examination of the relationship between materialism and individual values. Journal of Economic Psychology, 26, pp. 624-641.

Kim, H., Kim, W. (2005). The relationship between brand equity and firms' performance in luxury hotels and chain restaurants. Tourism Management, 26, pp. 549-560.

Kristensen,D., Creel, M. (2012). Estimation of dynamic latent variable models using simulated non-parametric moments, Econometrics Journal 15(3), pp. 490-515.

Lusk, J.L., Hudson, D. (2004). Willingness-to-Pay Estimates and Their Relevance to Agribusiness Decision Making. Review of Agricultural Economics, 26(2), pp. 152-169.

McKenzie, D. (1991). The rise of the green consumer. Consumer Policy Review, 1(2), pp. 68-75.

Miller, KM, Hofstetter R, Krohmer H., Zhang ZJ (2011). How should consumers' willingness to pay be measured? An empirical comparison of state-of-the-art approaches. Journal of Marketing Research 48(1), pp. 172-184.

Millock, K., Hansen, L.G. Wier, M., Anderson, L.M. (2002). Willingness to Pay for Organic products: A Comparison between Survey Data and Panel Data from Denmark, AKF Denmark.

Nordlund, A. M., Garvill, J. (2003). Effects of values, problem awareness and personal norm on willingness to reduce personal car use. Journal of Environmental Psychology, 23, pp. 339-347.

Orth, U. R., Wolf, M. M., Dodd, T. H. (2005). Dimensions of wine region equity and their impact on consumer preferences. The Journal of Product and Brand Management, 14(2-3), pp. 88-97.

Ottman, J. A. (2011). The new rules of green marketing: Strategies, tools and inspiration for sustainable branding. San Francisco, CA: Berrett-Koehler Publishers, Inc.

Roberts, J. (1996) Green consumers in the 1990s: Profile and implications for advertising. Journal of Business Research, 36(2), pp. 217-231.

Schultz, P. W. (2001). The structure of environmental concern: Concern for self, other people, and the biosphere. Journal of Environmental Psychology, 21, pp. 327-339.

Schultz, P. W., Gouveia, G. V., Cameron, L. D., Tankha, G., Schmuck, P., Franêk, M. (2005). Values and their relationship to environmental concern and conservation behavior. Journal of Cross-Cultural Psychology, 36, pp. 457-465.

Schultz, P. W., Shriver, C., Tabanico, J. J., Khazian, A. M. (2004). Implicit connections with nature. Journal of Environmental Psychology, 24, pp. 31-42.

Schwartz, S. H. (1994). Are there universal aspects in the structure and contents of human values? Journal of Social Issues, 50(4), pp. 19-45.

Schwartz, S. H., Howard, J. A. (1981). A normative decision-making model of altruism. In J.P. Rushton, R.M. Sorrentino (Eds.), Altruism and helping behavior (pp. 89-211). Hillsdale, NJ: Erlbaum.

Stern, P. C., Dietz, T., Kalof, L., Guagnano, G. A. (1995). Values, beliefs, and proenvironmental action: Attitude formation toward emergent attitude objects. Journal of Applied Social Psychology, 25, pp. 1611-1636.

Thøgersen, J. (2002). Direct experience and the strength of the personal norm behavior relationship. Psychology and Marketing, 19(10), pp. 881-893.

Titterington, A., Davies, C., Cochrane, A. (1996) Forty shades of green: A classification of green consumerism in Northern Ireland. Journal of Euro-Marketing, 5(3), pp. 43-55.

Umberger, W.J., Feuz, D.M., Calkins, C.R. Killinger, K. (2002). U.S. consumer preference and willingness-to-pay for domestic corn-fed beef versus international grass-fed beef measured through an experimental auction. Agribusiness 18, pp. 491-504.

Voelckner, F. (2006). An empirical comparison of methods for measuring consumers' willingness to pay. Marketing Letters, 17(2), pp. 137-149.

Webster, F. (1975). Determining the characteristics of the socially conscious consumer. Journal of Consumer Research, 2, 188-196.
Willingness to

Pay for Green Products vs Ecological Value System 